\title{
Periwinkle climbing response to water- and airbone predator chemical cues may depend on home-marsh geography
}

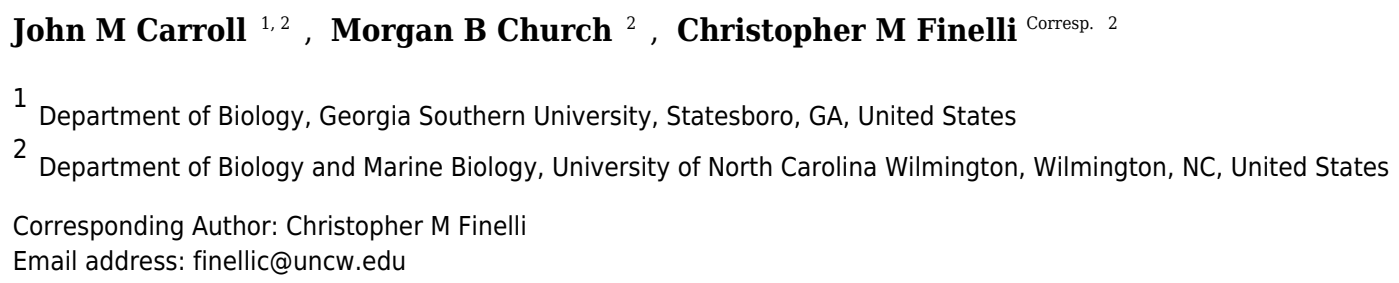

The salt marsh periwinkle, Littorina irrorata, exhibits a spatial refuge from predation by climbing the stems of Spartina alterniflora in order to avoid benthic predators. Salt marsh periwinkles have a broad geographic distribution, and for many species, responses to predators also varies with biogeography. This study sought to determine if the geographical location of the home marsh influenced the response of periwinkles (climbing height) to blue crab predator cues both via air and water. Snails from Louisiana (LA) climbed higher in general than those from North Carolina (NC), regardless of chemical cue. However, LA snails climbed $11 \mathrm{~cm}$ higher in the presence of waterborne predators than control snails with no cue, while NC snails only climbed $5 \mathrm{~cm}$ higher in the same comparisons. Airborne chemical cue tended to have snails climbing at intermediate heights. These responses were significantly enhanced when both populations of snails were housed together. Periwinkle response to predator cues was stronger in LA than NC, and so it is possible that the behavioral response of these snails to predators varies with biogeography of the home marsh. Also interestingly, the results of this study also suggest that cue delivery is probably occurring via mechanisms other than water, and potentially via airborne cues. Therefore, salt marsh periwinkles likely respond to numerous cues that initiate behavioral responses, including airborne cues, and these responses may vary by home-marsh geography. 
1 Periwinkle climbing response to water- and airborne predator chemical cues may depend on

2

3

4

5

6

7

8

9

10

11

12

13

14

15 home-marsh geography

John M. Carroll ${ }^{1,2}$, Morgan B. Church ${ }^{1}$, Christopher M. Finelli ${ }^{1 *}$

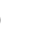

${ }^{1}$ Department of Biology and Marine Biology, University of North Carolina Wilmington,

7

Wilmington, NC 28403

${ }^{2}$ Present address: Department of Biology, Georgia Southern University, Statesboro, GA 30458

*Corresponding Author: Christopher Finelli, finellic@uncw.edu 
16 ABSTRACT - The salt marsh periwinkle, Littorina irrorata, exhibits a spatial refuge from

17 predation by climbing the stems of Spartina alterniflora in order to avoid benthic predators. Salt

18 marsh periwinkles have a broad geographic distribution, and for many species, responses to

19 predators also varies with biogeography. This study sought to determine if the geographical

20 location of the home marsh influenced the response of periwinkles (climbing height) to blue crab

21 predator cues both via air and water. Snails from Louisiana (LA) climbed higher in general than

22 those from North Carolina (NC), regardless of chemical cue. However, LA snails climbed $11 \mathrm{~cm}$

23 higher in the presence of waterborne predators than control snails with no cue, while NC snails

24 only climbed $5 \mathrm{~cm}$ higher in the same comparisons. Airborne chemical cue tended to have snails

25 climbing at intermediate heights. These responses were significantly enhanced when both

26 populations of snails were housed together. Periwinkle response to predator cues was stronger in

27 LA than NC, and so it is possible that the behavioral response of these snails to predators varies

28 with biogeography of the home marsh. Also interestingly, the results of this study suggest that

29 cue delivery is probably occurring via mechanisms other than water, and potentially via airborne cues. Therefore, salt marsh periwinkles likely respond to numerous cues that initiate behavioral responses, including airborne cues, and these responses may vary by home-marsh geography. 


\section{INTRODUCTION}

Predation is one of the most important interactions affecting marine populations (Connell 1975, Behrens Yamada, Navarrete \& Needham 1998). Predators can directly affect the distribution, abundance, size structure and genetic make-up of prey populations (Menge 1983, Yoshida et al., 2003). As a result of intense predation pressure, prey have evolved various means to reduce predation risk that vary on ecological and evolutionary timescales (Vermeij 1982, Trussell and Smith 2000). For example, natural selection is thought to drive changes in prey morphology over evolutionary timescales, with prey growing thicker, more ornate exoskeletons in response to high or increasing predation pressure (Vermeij 1982, 1983, 1987). However, prey can respond to predators at ecological (within lifetime) timescales (Lima and Dill 1990). In particular, predators have increasingly been demonstrated to rapidly induce prey defenses, which act to reduce prey vulnerability (Trussell and Smith 2000). These inducible defenses occur across diverse taxa and include fast growth, chemical defenses, skeleton thickening, changes in behavior, and using refugia (Harvell 1990, Berenbaun and Zangerl 1999).

A number of gastropods have demonstrated inducible defenses as a result of predation pressure in experimental settings (Behrens Yamada, Navarrete \& Needham 1998, Brandwood 1985, Duncan and Szelistowski 1998, Large and Smee 2010, 2013). A common defense is changing behavior, including predator avoidance and/or fleeing (Legault and Himmelman 1993). However, these defenses typically vary across broad georgraphic scales. Both predator diversity and predation pressure generally vary inversely with latitude, so prey organisms have responded by increasing defenses with decreasing latitude (Laurila, Lindgren \& Laugen 2008, Freestone et al. 2011), which includes latitudinal differences in behavioral responses (Aschaffenburg 2008, Donahue et al. 2009, Duval, Calzetta \& Rittschof 1994, Large and Smee 2013). Induced 
57 defenses are affected at broad biogeographic scales by differences in environmental conditions

58

59

60

61

62

63

64

and stimuli (Trussell and Smith 2000). Further, there are costs associated with induced defenses (Trussell and Nicklin 2002), so geographic patterns in prey response likely reflect the greater predictability of predation risk at certain locations (Trussell and Smith 2000).

For intertidal snails, predator avoidance includes using spatial refugia to avoid capture which has been demonstrated in both rocky-interidal (Menge and Lubchenco 1981) and salt marsh habitats (Warren 1985). The salt marsh periwinkle, Littorina irrorata Say, is an important resident of tidal marshes along the US Atlantic and Gulf coasts, which exhibit spatially variable distribution dependent upon the tidal stage (Hovel, Bartholomew \& Lipcius 2001). Historically, the distribution of periwinkles in the salt marsh was initially considered to be the result of environmental variables (Bingham 1972). However, considerable evidence suggests this vertical distribution is to avoid predators when the tide returns, such as the blue crab, Callinectes sapidus Rathbun, and the crown conch, Melongena corona Gmelin (Hamilton 1976, Warren 1985), and perwinkles tend to migrate higher and/or faster in the presence of predators (Dix and Hamilton 1993, Duval, Calzetta \& Rittschof 1994, Kimbro 2012, Wollerman, Duva \& Ferrier 2003), although these activities are constrained by environmental stressors, such as temperature (Iacarella and Helmuth 2012). Thus, periwinkles exhibit a spatial refuge from predation by climbing the stems of salt marsh cordgrass, Spartina alterniflora Loisel, in order to avoid benthic predators (Dix and Hamilton 1993, Vaughn and Fisher 1988).

L. irrorata has an extensive geographic range (Bingham 1972) and climbing behavior has been noted at the local scale in Virginia (Stanhope, Banta \& Temkin 1982), North Carolina (Duval, Calzetta \& Rittschof 1994, Lewis and Eby 2002), Georgia (Silliman and Bertness 2002), Florida (Hamilton 1976, Warren 1985), Alabama (Henry, McBride \& Williams 1993), Louisiana 
80 (pers. obs.) and Texas (Vaughn and Fisher 1988). Since predator diversity and predation

81 pressure vary with latitude (Bertness, Garrity \& Levings 1981, Freestone et al. 2011), and salt

82 marsh periwinkles inhabit this broad geographic range, they are useful model organisms to

83 explore biogeographic variation in behavioral responses. Regional comparisons in climbing

84 height and response to predators in marsh periwinkles have not been made previously, although

85 a number of other similar species have exhibited differential responses to predators across

86 geographic ranges (Fawcett 1984, Large \& Smee 2013). Therefore, periwinkles might exhibit

87 similar differences in induced avoidance responses according to home-marsh geography.

88 The mechanism thought to be driving climbing behavior is response to waterborne chemical cues from either predators or injured conspecifics (Duval, Calzetta \& Rittschof 1994, 90 Jacobsen and Stabell 1999), although periwinkles often migrate in advance of the tide. For other intertidal snails, such as Cerithidea decollata, it has been suggested that there is an internal clock that might drive migrations (Lazzeri et al. 2014), however L. irrorata has been demonstrated to rapidly respond to out of phase tidal cycles in the lab (Hovel, Bartholomew \& Lipcius 2001). It

94 is possible that some cues might become aerosolized prior to the arrival of the incoming tide, 95 forewarning snails and cueing them to start climbing (Lazzeri 2017). A number of terrestrial gastropods respond to airborne cues for homing (Chelazzi, Le Vovi \& Parpagnoli 1988), feeding

97 (Davis 2004), mating (Ng et al. 2013), and avoiding predators (Bursztyka et al. 2013). Interestingly, it has been suggested that at least two species of intertidal snails may respond to airborne cues from either food (Fratini, Cannicci \& Vannini 2001) or the environment (Lazzeri 2017). Given the responses to other airborne chemical cues, it is possible that intertidal marine gastropods would also react to airborne cues from predators, particularly snails such as $L$. 
102 irrorata, which spend much of their time emersed. Yet, responses to potential airborne chemical 103 cues from predators has not been investigated in Littorinids.

Relatively little is known about how species might respond to different chemical cues

105

106

107

108

109

110

111

112

113

114

115

116

117

118

119

120

121

122

123

across geographical locations. Due to its geographic range and behavior, the marsh periwinkle is a useful model organism to explore whether geographic location and the presence of airborne cues affects anti-predator behavioral responses. Further, periwinkles could also be a useful model organism to see whether behavioral responses change in the presence of individuals from different populations, which may come into contact due to human activities. Field observations in Louisiana demonstrated that periwinkles responded to crabs by climbing up Spartina alterniflora, however, similar field observations in North Carolina suggested a lesser response. Thus, we designed a controlled lab experiment to investigate the difference in behavioral response (climbing) of two periwinkle populations to cues from a common predator, the blue crab Callinectes sapidus. Specifically, we tested whether the presence of both waterborne and airborne blue crab cues would cause snails to migrate up Spartina mimics, and whether the two populations would climb to different heights. Since behavioral responses to predation are likely to vary at different geographic locations and predation pressure often increases with decreasing latitude, we hypothesized the Louisiana population of periwinkles would show a greater response to the predator than the North Carolina population by migrating higher on the mimics. Additionally, since intertidal salt marsh periwinkles spend the majority of their time out of the water, we hypothesized that airborne cues would elicit a behavioral response, although given the marine origin of this species, we expected the airborne response to be intermediate.

\section{METHODS AND MATERIALS}


Louisiana Universities Marine Consortium $\left(29^{\circ} 15^{\prime} 20.65^{\prime \prime} \mathrm{N}, 90^{\circ} 39^{\prime} 42.93^{\prime \prime} \mathrm{W}\right)$ and transported to

126

127

128

129

130

131

132

133

134

135

136

137

138

139

140

141

142

143

144

145

146

North Carolina. North Carolina snails were collected from the salt marsh adjacent to the Center

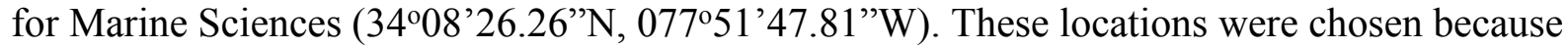

they are within the range of L. irrorata and they share an abundant common predator, blue crabs. In order to acclimate snails to laboratory conditions, individuals were held in the lab for 2 days prior to the start of the experiment since the species has been shown to rapidly $(\sim 1 \mathrm{~d})$ respond to changes in tidal conditions in the lab (Hovel, Bartholomew \& Lipcius 2001). Snails were provided with Spartina as a food resource during the holding period. Blue crabs were purchased from a local supplier. All animals were kept in flowing filtered seawater holding tanks. Crabs were fed crushed snails ad libitum for 48 hours prior to use in experiments.

Lab assays were conducted to investigate regional differences in climbing and to test for chemical cue responses. The experimental unit was a box-in-box mesocosm set-up (Figure 1A). Briefly, we placed a small plastic tub $(27 \times 41 \times 18.5 \mathrm{~cm})$, used to house the periwinkles during the experiment, within a larger plastic tub $(39 \times 54 \times 16 \mathrm{~cm})$. Spartina-mimics were used to simulate marsh grass in lab assays (Hovel, Bartholomew \& Lipcius 2001). Eight $75 \mathrm{~cm}$ tall x $1.5 \mathrm{~cm}$ wide PVC pipes were used in each replicate. The PVC mimics were preferable to natural grass because they are inert (Sueiro, Bortlous \& Schwindt 2012), can be easily washed between trials, and are not likely to give off chemical cues like wooden dowel rods or Spartina stems. In crab water cue treatments, the small, inner plastic tubs were drilled with small holes to allow water to mix between the inner and outer tubs when filled (Figure 1A). For airborne cues and no cue treatments, the inner boxes were not drilled in order to isolate the water in the small tub.

However, the airborne cue treatments held a crab in the outer box, whereas no cue treatments did 
147 not receive a crab. Plastic mesh was used to cover the space between the small and large tubs to 148 prevent movement of animals between the tubs (Figure 1B). We used six box-in-box set-ups per

149 trial for the experiments. Air stones, modified to reduce splashing, were placed in the outer tub

150 for all treatments. Each experimental unit was surrounded on four sides by a $45 \times 64$ x $90 \mathrm{~cm}$

151 open top cage constructed of PVC pipe and a thick black plastic curtain to isolate the replicates

152 from each other, preventing potential transfer of airborne cues between units and reducing the

153 visual disturbance on both snails and crabs. Fluorescent work lights were provided directly

154 above each experimental unit. Temperature was maintained at $28^{\circ} \mathrm{C}$ in holding tanks and 155 experimental units.

156 Three different treatments were established - a no crab control, a crab present with 157 chemical cues mixing via water exchange between tubs, and a crab present with no water 158 exchange. For the no crab control, $\sim 26 \mathrm{~L}$ of clean, filtered and sterilized seawater was placed 159 into the two tubs, for a water depth of $12.5 \mathrm{~cm}$. For the crab present treatments, crabs were 160 placed in the large outer tub and allowed to move freely throughout the space between the tubs.

161 For the waterborne cue, the small, inner tubs drilled to allow water exchange were used, 162 circulating the water between tubs and allowing snails to contact water exposed to the blue crab.

163 For the non-waterborne cue, tubs that were not drilled were used, restricting both the crab and 164 crab-cue water to the outer tub, and thus the snails could not directly sample water with crab 165 cues. These tubs were covered with a mesh top which allowed airborne cues to escape. Our 166 mesocosms were undisturbed during the experiment to minimize stimulation of test subjects. We 167 did not notice surface splashing by crabs, they were either stationary or remained submerged for 168 the duration of the trials. Thus any response in these treatments is indicative of an airborne cue. 
Two sets of experiments were conducted. The first set used either LA or NC snails alone,

170

171

172

173

174

175

176

177

178

179

180

181

182

and two trials were used for each of the NC and LA snails. Sets of 30 snails were placed directly on the PVC approximately $5 \mathrm{~cm}$ above the water line $(\sim 17 \mathrm{~cm}$ above the bottom of the tubs $)$ in each mesocosm set-up $(n=180$ total snails per trial) and exposed to the different treatments for 6 hours. Observations of snails demonstrated that many initially approached and entered the water at the start of the experiment. Since the airborne cue was the target of the investigation, each trial had airborne cue treatments. However, due to space limitations for the experimental set-ups, waterborne cue and no cue treatment replicates were only used in a single trial.

To eliminate any perceived differences between populations that might have been due to running separate experiments, we conducted a second common garden experiment where we combined snails from the two populations. For the second experiment, we also used 2 trials, although to keep density per mesocosm the same, we only used 15 snails per home marsh. This allowed us to directly examine the two populations in the same experimental conditions. At the end of each trial, the height of each individual snail was measured.

For the single population experiments, North Carolina and Louisiana trials were combined and analyzed. A two-factor generalized linear mixed model (GLMM) was used to determine the effect of site and cue treatment on average climbing height of snails. Site (NC or LA) and cue treatment (no cue, airborne cue, waterborne cue) were modeled as a fixed effect. Since 30 snails were placed into each tub for the experiment, snails within each tubs could not be considered independent of each other (Supplement 1). To account for potential effects of snails located within the same tub, a tub identifier was included as a random effect in the model. GLMMs were also used to determine the effect of home marsh and cue type in the mixed population experiment, with treatment (no cue, airborne cue, waterborne cue) and location (NC 
192 and LA) as fixed effects, and tub modeled as a random effect. Models were fit with the function

193 'glmer' and a gamma distribution using the 'lme4' package (Bates et al. 2015) in R (R Core

194 Team 2015). When significant effects were found, post-hoc general linear hypothesis

195 comparisons were performed using 'ghlt' function 'multcomp' package in R (Hothorn, Bretz \&

196 Westfall. 2008).

197 RESULTS

Snails actively moved up and down the PVC mimics during the experimental period. LA snails climbed significantly higher than NC snails $(\mathrm{p}<0.001)$, although there was a significant interaction between the two fixed factors $(\mathrm{p}<0.001)$, suggesting the response in the different snail populations varied dependent upon the cue treatment (Figure 2). There was a trend in the LA snails to climb higher when exposed to predator cues, although there was high variability within each treatment, and these trends were not significant (Figure 2). The minimum height for waterborne cue boxes was $16.4 \mathrm{~cm}$, whereas it was 19.3 for airborne cue and 22.5 for control boxes. The maximum was similar for all $(74.8 .76 .5$ and $76.4 \mathrm{~cm}$ for waterborne, airborne and control boxes. No individuals were below the water line at the end of the experiment. The within trial variability in mean snail height among boxes of the same treatments was 5.4, 12.6, and 2.9 $\mathrm{cm}$ for waterborne, airborne and control treatments, respectively.

For NC snails, there was also a trend for those exposed to waterbone crab cues to climb higher than those with no cue (Figure 2), although like in the LA snail population, there was considerable variability among individuals. Interestingly, the minimum height for NC snails was $4.8,0$, and $0 \mathrm{~cm}$ for the waterborne, airborne and control treatments, respectively. The maximum

213 height climbed in the waterborne cue was $66.3 \mathrm{~cm}$, whereas the maximum height in the airborne cue was $68.5 \mathrm{~cm}$. The maximum height climbed in the control boxes was lower $(51.6 \mathrm{~cm})$. 
215 Across all control boxes, 27\% of the individuals were submerged at the end of the trial, while

$21636 \%$ of snails in the airborne boxes and only $11 \%$ of snails in the waterborne boxes were

217 submerged. As with LA snails, there was also within trial variability in mean height across

218 boxes of the same treatments. Mean height varied by 5.3, 10.9 and $5.2 \mathrm{~cm}$ across boxes in the

219 waterborne, airborne and control treatments, respectively.

220 When snail populations were placed together, there were significant treatment and

221 location effects $(\mathrm{p}<0.001$ for both $)$, but no significant interaction $(\mathrm{p}=0.585$; Table 1$)$. LA snails

222 climbed significantly higher $(41.4 \pm 1.2 \mathrm{~cm}$, mean $\pm \mathrm{SE})$ than NC snails $(22.8 \pm 1.2, \mathrm{p}<0.001)$

223 across all treatments (Figure 3A). In addition, across both sites, snails in the airborne (38.3 \pm 1.6

$224 \mathrm{~cm})$ and waterborne $(36.7 \pm 1.8 \mathrm{~cm})$ cues climbed significantly higher than those in no cue

225 treatments $(21.8 \pm 1.3 ; \mathrm{p}<0.001$ for both $)$. Climbing heights in the presence of airborne or

226 waterborne cues were not different from each other $(p=0.648$; Figure $3 B)$. Within the mixed

227 treatment, LA snails in the presence of crab cues climbed between 19 and $24 \mathrm{~cm}$ higher on

228 Spartina mimics than those not exposed to crab cues, whereas NC snails climbed between 9 and

$22910 \mathrm{~cm}$ higher when crab cues were present versus absent.

\section{DISCUSSION}

Marsh periwinkles have an inducible defense that they exhibit over their broad

232 geographic range, making them an ideal model species of examining geographic variation in

233 predator avoidance behavior. In this study, salt marsh periwinkles from both populations

234 responded to the presence of blue crabs by migrating higher up Spartina mimics than those in 235 control treatments, a result consistent with earlier findings (Warren 1985), although here the 236 differences were more apparent when the snails were housed in mixed population treatments.

237 However, it was previously unknown whether the behavioral response, in this case migration 
238 distance, might be greater in the lower latitudes. Snails from Louisiana demonstrated a stronger

239 response by migrating farther up the mimics when kept in both the single population and mixed

240 assemblages than their North Carolina counterparts. This mimicked our field observations at

241 both LA and NC, where LA periwinkles consistently and reliably climbed up Spartina

242 alterniflora stems in response to crab odors, including airborne cues, while those in NC were less

243 consistent in their response. It is therefore possible that the behavioral response of $L$. irrorata to

244 crab presence varies geographically.

245 Several environmental factors may have influenced marsh periwinkle vertical migration

246 (Bingham 1972, Henry, McBride \& Williams 1993), including tidal regime (Kimbro 2012).

247 Louisiana snails in our experiment consistently climbed higher than North Carolina snails, even

248 in the absence of predator cues. The snails should have become entrained with their new

249 conditions in the lab, since periwinkles have been demonstrated to rapidly respond to changing

250 tidal cycles and constant water depth (Hovel, Bartholomew \& Lipcius 2001). Further, the tidal

251 amplitude in NC ( $2 \mathrm{~m})$ is greater than in LA $(<0.5 \mathrm{~m}$; Wang, Lu \& Sikora 1993), so we might

252 expect snails from NC to climb higher if amplitude was engrained in their behavioral response.

253 Thus, our observations of snail climbing was opposite the home marsh tidal amplitudes. The

254 different heights between populations in the no predator treatments is unclear. Perhaps the

255 smaller, diurnal tidal range which results in more prolonged periods of marsh flooding

256 experienced in Gulf Coast marshes like LA (Eleuterius \& Eleuterius 1979) entrains local snail

257 populations to remain higher when there is water present, since their ecological history suggests

258 some predictability in predation risk. This would suggest some localized adaptation in the

259 induced behavioral response (Trussell \& Smith 2000), and further support that different climbing

260 heights is representative of a predator response, even if it is only a site-effect. 
There are a number of mechanisms that might influence prey response to predators,

262 including both physical and biotic, and unfortunately, these are difficult to elucidate without further experimentation and more sample sites along the geographic range of periwinkle snails. However, in our controlled setting, snails from LA consistently climbed higher than the NC snails. Biotic history and predator differences between the home marshes is a possible explanation for the differential behavioral responses. Although we did not measure crab abundance at the two collection sites, it is possible that there are differences between sites due to geographic locality (Figure 4). Predation pressure varies biogeographically, with predation increasing as latitude decreases (Bertness, Garrity \& Levings 1981, Peterson et al. 2001), and numerous prey have responded by increasing defenses along this predation pressure gradient (Bertness, Garrity \& Levings 1981, Freestone et al. 2011, Vermeij 1982). Further, predator identity and species composition, which can vary biogeographically, also lead to differential responses in prey species (Large and Smee 2013). Multiple gastropods exhibited different avoidance behaviors across a broad temperate to tropical latitudinal gradient as a result of increased predator diversity (Bertness, Garrity \& Levings 1981). It is therefore possible that the observed differences in climbing height between the Louisiana and North Carolina populations of $L$. irrorata in our experiment might reflect differences in predation pressure experienced by the snails at their home marshes.

Unfortunately, it is difficult to make broad conclusions about geographic differences using only two study sites, and intraspecific trait variation could be due to a number of other factors that may vary independent of geographic location. For example, parasite load could reduce snail behavioral responses to predators (Belgrad \& Smith 2014), and it is unclear whether snails from either site had a higher parasite load which was beyond the scope of this experiment. 
284 Additionally, there could be other factors beyond predation pressure that could result in different

285 climbing responses. While our periwinkles were offered food prior to the experiment, biotic

286 history and tissue condition could play a role in response, as hungrier individuals may be more

287 risky (Gilliam \& Fraser 1987), and other metrics of condition can alter activity (Pardo \& Johnson

288 2004). Although we controlled for hunger by feeding the snails while they were in captivity, the

289 history prior to capture for this experiment could have played a role in site differences.

290 Regrettably, we did not measure condition of the snails after experiments. Additionally, size and

291 shell morphology (i.e., thickness, aperture size, spire length, etc.) might vary across locations for 292 snails (Sepulveda \& Ibanez 2012, Ramajo et al. 2013, Kosloski, Dietl \& Handley 2016), and

293 could alter their escape responses to predators. Although we sought to use similarly-sized

294 periwinkles from both locations, we did not measure morphometric variables. Finally, it is

295 possible that even though blue crabs are common at both locations, we only used blue crabs

296 collected locally in NC for our experiments, potentially leading to LA snails that were more

297 alarmed by water- and airborne cues from a less familiar population of blue crabs, resulting in an

298 exaggerated response. Regardless of the mechanism driving the differential responses, the snails 299 collected in LA snails exhibited stronger responses to predators in our study system.

In addition, the results of this study demonstrate that periwinkles are likely responding to airborne predator cues, a novel observation for an intertidal, marine snail. When the crab was present but water was not allowed to exchange, there appeared to be an intermediate response in single population assemblages with LA snails, resulting in snails climbing $\sim 5 \mathrm{~cm}$ higher than the no cue treatment snails. While this was not a statistically significant difference, it is the same size of the response in the NC snails with the waterborne cue. It is possible that a volatile compound given off by the crab can become aerosolized and perceived by the periwinkles. This 
307 has not been previously documented for marine organisms, however, chemosensory cues are 308 common in terrestrial fauna, including gastropods (Chase et al., 1978, Croll 1983), and a variety

309 of aqueous compounds can be transported via the air, including HAB toxins (Fleming, Backer \&

310 Baden 2005), as well as pyrazines, trimethylamine and dimethyl sulfide DMS (Nevitt 2000).

311 Terrestrial gastropods use airborne cues for homing, mating, and finding food (Croll 1983,

312 Chelazzi, Le Voci \& Parpagnoli 1988), as well as to avoid predators (Bursztyka et al., 2013,

313 Lefcort, Ben-Ami \& Heller 2006). The response to airborne cues from predators has not been

314 identified for other marine, intertidal snails, although, there is some indication that intertidal

315 snails respond to airborne food (Fratini, Cannicci \& Vannini 2001) and habitat cues (Lazzeri

316 2017). Since marsh periwinkles spend much of their time out of the water, it is possible they

317 could also be sensitive to airbone cues, and our experimental design was such that all of the

318 snails could have been responding to airborne cues. It is beyond the scope of this experiment to

319 determine which compound is becoming aerosolized and stimulating a response in periwinkles,

320 but that such a chemical might exists warrants further attention.

We also note that snail response to cues only became significantly different when the two populations were mixed; that is regardless of origin, snails in mixed assemblages climbed at least twice as high as snails in single population assemblages in response to predator presence. This result is particularly interesting, because it suggests that some alteration in behavior might occur 325 if distinct populations of the same species come into contact. While the probability of LA snails encountering $\mathrm{NC}$ snails in the field is low, rafted plant material can transport and disperse fauna 327 great distances (Theil \& Fraser 2016), tens to hundreds of kilometers (Dame 1982, Thiel \&

328 Gutow 2005, Thiel and Fraser 2016). Further, climate change related distribution shifts (Barry et 329 al. 1995, Zacherl, Gaines \& Lonhart 2003, Mieszkowska et al. 2007, Poloczanska et al. 2013) 
330 might lead populations of snails with different predator responses to interact with each other.

331 Thus, it is increasingly likely that distinct populations with different predator responses can come

332 into contact with each other. In the predator cue treatments, it is possible that there was some

333 avoidance between the populations, although the pattern of higher climbing was not observed in

334 the mixed assemblage no cue control treatments. More likely, mixing the two populations

335 together may have led to amplified alarm cues and signaling to other snails. Alarm cues are

336 common, and while typically emitted from injured conspecifics (Jacobsen and Stabell 1999),

337 they could also come from disturbed, but undamaged, conspecifics (Jacobsen and Stabell 2004).

338 Alternatively, the periwinkles could have been responding to mucus trails of the other

339 populations. Conspecific mucus trails have been shown to aid in navigation, homing,

340 aggregation, and mating ( $\mathrm{Ng}$ et al. 2013), and trails may also be a source of nutrition (Davies and

341 Beckwith 1999). Further, periwinkles may respond to both predator and alarm cues in mucus

342 trails (Duval, Calzetta \& Rittschof 1994, Ng et al. 2013). The mechanism for the heightened

343 response in mixed assemblages is unclear, and this experiment was unfortunately not designed to

344 examine this. However, why this response might change in single population vs. mixed

345 assemblages should be pursued in the future.

\section{CONCLUSIONS}

This study demonstrates that geographic origin likely influences the behavioral response

to a common predator for periwinkles. It is possible that the differential response to the common

predator might be due to different abundance/distribution of blue crabs at the Louisiana/North

350 Carolina home marshes, or just general trends of higher predator density/diversity with

351 decreasing latitude. While further studies are required across more sites to ensure our

352 observations are not just a site effect, these results are promising. In addition, this study is the 
353 first to demonstrate that these intertidal snails may also respond to airborne cues from predators.

354 Although the chemical is unknown, that some volatile compound might become aerosolized and

355 illicit a behavioral response in littorinid snails should be explored further. The broad geographic

356 range and behavioral responses of Littorina irrorata make it a useful model organism to explore

357 responses to waterborne, airborne, and even mucus-bound predator and alarm cues. Future work

358 should investigate responses of snails from multiple locations along their biogeographic

359 distribution, across multiple predator species which might also vary in abundance throughout the

360 periwinkles' range, and identify compounds from predators and injured conspecifics that might

361 become aerosolized.

\section{ACKNOWLEDGEMENTS}

363 We would like to thank T. Bleier of the University of North Carolina Wilmington and 364 other members of the Marine Biofluiddynamics and Ecology Lab (MARBEL) for help

365 conducting lab experiments. We would also like to acknowledge Dr. Laura Treible of UNCW

366 for assistance in statistical analysis. 
367

368

369

370

371

372

373

374

375

376

377

378

379

380

381

382

383

384

385

386

387

388

389

\section{LITERATURE CITED}

Aschaffenburg, M. 2008. Different crab species influence feedng of the snail Nucella lapillus through trait-mediated indirect interactions. Marine Ecology 29:348-353.

Barry JP, Baxter CH, Sagarin RD, Gilman SE. 1995. Climate-related, long-term faunal changes in a California rocky intertidal community. Science 267:672-675.

Bates D, Mächler M, Bolker B, Walker S (2015) Fitting Linear Mixed-Effects Models Using lme4. Journal of Statistical Software 67

Behrens Yamada S, Navarrete S, Needham C. 1998. Predation induced changes in behavior and growth rate in three populations of intertidal snail, Littorina sitkana (Philippi). Journal of Experimental Marine Biology and Ecology. 220:213-226.

Berenbaum MR, Zangerl AR. 1999. Coping with life as a menu option: Inducible defenses of the wild parsnip. In: The Ecology and Evolution of Inducible Defenses. Tollrain R, Harvell CD eds. Princeton University Press. Pg 10-32

Bertness M, Garrity S, Levings S. 1981. Predation pressure and gastropod foraging: a tropical-temperate comparison. Evolution 35:995-1007.

Bingham F. 1972. The influence of environmental stimuli on the direction of movement of the supralittoral gastropod Littorina irrorata. Bulletin of Marine Science 22:309-335.

Brandwood A. 1985. The effects of environment upon shell construction and strength in the rough periwinkle Littorina rudis Maron (Mollusca: Gastropoda). Journal of Zoology. 206:551-565.

Bursztyka P, Saffray D, Lafont-Lecuelle C, Brin A, Pageat P. 2013. Chemical compounds related to the predation risk posed by malacophagous ground beetles alter selfmaintenance behavior of niave slugs (Deroceras reticulatum). PLoS ONE 8:e79361. 
390

391

392

393

394

395

396

397

398

399

400

401

402

403

404

405

406

407

408

409

410

411

412

Chase R, Pryer K, Baker R, Madison D. 1978. Responses to conspecific chemical stimuli in the terrestrial snail Achatina fulica (Pulmonata: Sigmurethra). Behavioral Biology 22:302315.

Chelazzi G, Le Voci G, Parpagnoli D. 1988. Relative importance of airborne odours and trails in the group homing of Limacus flavus (Linnaeus) (Gastropods, Pulmonata). Journal of Molluscan Studies 54:173-180

Croll R. 1983. Gastropod chemoreception. Biological Review 58:293-319.

Dame RF. 1982. The flux of floating macrodetritus in the North inlet estuarine ecosystem. Estuarine, Coastal and Shelf Science 15:337-344

Davies MS, Beckwith P. 1999. Role of mucus trails and trail-following in the behavior and nutrition of the periwinkle Littorina littorea. Marine Ecology Progress Series 179: 247257

Dix T, Hamilton P. 1993. Chemically mediated escape behavior in the marsh periwinkle Littoraria irrorata Say. Jounral of Experimental Marine Biology and Ecology 166:135149.

Donahue M, Nichols A, Santamaria C, League-Pike P, Krediet C, Perez K, Shulman MJ. 2009. Predation risk, prey abundance, and the vertical distribution of three brachyuran crabs on Gulf of Maine shores. Journal of Crustacean Biology 29:523-531.

Duncan R, Szelistowski W. 1998. Influence of puffer predation on vertical distribution of mangrove littorinids in the Gulf of Nicoya, Costa Rica. Oecologia 117:433-442.

Duval M, Calzetta A, Rittschof D. 1994. Behavioral responses of Littoraria irrorata (SAY) to water-borne odors. Journal of Chemical Ecology 20:3321-3334.

Eleuterius LN, Eleuterius CK. 1979. Tidal levels and salt marsh zonation. Bulletin of Marine 
414 Fawcett MH. 1984. Local and latitudinal variation in predation on an herbivorous marine snail.

415

416

417

418

419

420

421

422

423

424

425

426

427

428

429

430

431

432

433

434

435

Ecology 65:1214-1230

Fleming L, Backer L, Baden D. 2005. Overview of aerosolized Florida red tide toxins: Exposures and effects. Environmental Health Perspectives 113:618-620.

Fratini S, Vannini M, Cannici S. 2008. Feeding prederences and food searching strategies mediated by air- and water-borne cues in the mud whelk Terebralia palustris (Potamididae: Gastropoda). Journal of Experimental Marine Biology and Ecology 362: 26-31.

Freestone A, Osman RW, Ruiz G, Torchin M. 2011. Stronger predation in the tropics shapes species richness patterns in marine communities. Ecology 92:983-993.

Gilliam JF, Fraser DF. 1987. Habitat selection under predation hazardL test of a model with foraging minnows. Ecology 68:1856-1862

Hamilton P. 1976. Predation on Littorina irrorata (Mollusca:Gastropoda) by Callinectes sapidus (Crustacea:Portunidae). Bulletin of Marine Science 26:403-409.

Harvell CD. 1990. The ecology and evolution of inducible defenses. Quarterly Reviews in Biology 65:323-340.

Henry R, McBride C, Williams A. 1993. Responses of the marsh periwinkle, Littoraria (Littorina) irrorata to temperature, salinity and dessication, and the potential physiological relationship to climbing behavior. Marine Behavior and Physiology 24:4554.

Hothorn T, Bretz F, Westfall P. 2008. Simultaneous Inference in General Parametric Models. Biometry Journal 50:346-363 
436 Hovel K, Batholomew A, Lipcius R. 2001. Rapidly entrainable tidal vertical migrations in the

437

438

439

440

441

442

443

444

445

446

447

448

449

450

451

452

453

454

455

456 salt marsh snail Littoraria irrorata. Estuaries 24:808-816.

Iacarella JC, Helmuth B. 2012. Body temperature and desiccation constrain the activity of Littoraria irrorata within the Spartina alterniflora canopy. Thermal Biology 37:15-22

Jacobsen H, Stabell O. 1999. Predator-induced alarm responses in the common periwinkle, Littorina littorea: dependence on season, light conditions, and chemical labelling. Marine Biology 134:551-557.

Jacobsen H, Stabell O. 2004. Antipredator behaviour mediated by chemical cues: the role of conspecific alarm signalling and predator labelling in the avoidance response of a marine gastropod. OIKOS 104:43-50.

Kimbro D. 2012. Tidal regime dicates the cascading consumptive and noncomptive effects of multiple predators on a marsh plant. Ecology 93:334-344.

Kosloski ME, Dietl GP, Handley JC. 2016. Anatomy of a cline: dissecting anti-predatory adaptations in a marine gastropod along the US Atlantic coast. Ecography 40:1285-1299

Large S, Smee DL. 2010. Type and nature of cues used by Nucella lapillus to evaluate predation risk. Journal of Experimental Marine Biology and Ecology 296:10-17.

Large S, Smee DL. 2013. Biogeographic variation in behavioral and morphological responses to predation risk. Oecologia 171:961-969.

Laurila A, Lindgren B, Laugen A. 2008. Antipredator defenses along a latitudinal gradient in Rana temporaria. Ecology 89:1399-1413.

Lazzeri AM, Bazihizina N, Kingunge PK, Lotti A, Pazzi V, Tasselli PL, Vannini M, Fratini S. 
457

458

459

460

461

462

463

464

465

466

467

468

469

470

471

472

473

474

475

476

477

478

479

2014. Migratory behavior of the mangrove gastropod Cerithidea decollata under unfamiliar conditions. Journal of Experimental Marine Biology and Ecology 457:236240

Lazzeri AM. 2017. Possible environmental chemical cues affecting behavior of the mangrove gastropod Cerithidea decollata. Estuarine, Coastal and Shelf Science 188: 12-17

Lefcort H, Ben-Ami F, Heller J. 2006. Terrestrial snails use predator-diet to assess danger. Journal of Ethology 24:97-102.

Legault C, Himmelman J. 1993. Relation between escape behavior of benthic marine invertebrates and the risk of predation. Journal of Experimental Marine Biology and Ecology 170:55-74.

Lewis D, Eby L. 2002. Spatially heterogeneous refugia and predation risk in intertidal salt marshes. OIKOS 96:119-129.

Lima S, Dill L. 1990. Behavioral decisions made under the risk of predation: a review and prospectus. Canadian Journal of Zoology 68:619-640.

Menge B. 1983. Components of predation intensity in the low zone of the New England rocky intertidal region. Oecologia 58:141-155.

Menge B, Lubchenco J. 1981. Community organization in temperate and tropical rocky intertidal habitats: Prey refuges in relation to consumer pressure gradients. Ecological Monographs 51:429-450.

Mieszkowska N, Hawkins SJ, Burrows MT, Kendall MA. 2007. Long-term changes in the geographic distribution and population structures of Osilinus lineatus (Gastropoda: Trochidae) in Britain and Ireland. Journal of the Marine Biological Association of the United Kingdom 87:537-545. 
480 Nevitt, GA. 2000. Olfactory foraging by Antarctic Procellariiform seabirds: life at high

481 Reynold's number. Biological Bulletin 198:245-253.

482 Ng TPT, Saltin SH, Davies MS, Johannesson K, Stafford R, Williams GA. 2013. Snails and their

483

484

485

486

487

488

489

490

491

492

493

494

495

496

497

498

499

500

501 trails: the multiple functions of trail-following in gastropods. Biolical Reviews 88:683700

Odum E, Smalley A. 1959. Comparison of population energy flow of a herbivorous and a deposit-feeding invertebrate in a salt marsh ecosystem. Proceedings of the National Academy of Science 45:617-622.

Pardo LM, Johnson LE. 2004. Activity and shelter use of an intertidal snailL effects of sex, reproductive condition and tidal cycle. Journal of Experimental Marine Biology and Ecology 301:175-191.

Peterson BJ, Thompson K, Cowan J, Heck KJ. 2001. Comparison of predation pressure in temperature and subtropical seagrass based on chronographic tethering. Marine Ecology Progress Series 224:77-85.

Poloczanska ES, Brown CJ, Sydeman WJ, Kiessling W, Schoeman DS, Moore PJ, Brander K, Bruno JF, Buckley LB, Burrows MT, Duarte CM, Halpern BS, Holding J, Kappel CV, O’Connor MI, Pandolfi JM, Parmesan C, Schwing F, Thompson SA, Richardson AJ. 2013. Global imprint of climate change on marine life. Nature Climate Change 3:919925.

R Core Team (2015) R: A language and environment for statistical computing. R Foundation for Statistical Computing, Vienna, Austria. URL https:/www.R-project.org/.

Ramajo L, Baltanas A, Torres R, Manriquez PH, Rodriguez-Navarro A, Lagos NA. 2013. 
502

503

504

505

506

507

508

509

510

511

512

513

514

515

516

517

518

519

520

521

522

523

524

Geographical variation in shell morphology of juvenile snails (Concholepas concholepas) along the physical-chemical gradient of the Chilean coast. Journal of the Marine Biological Association of the United Kingdom 93:2167-2176

Sepulveda RD, Ibanez CM. 2012. Clinal variation in the shell morphology of intertidal snail Acanthina monodon in the Southeastern Pacific Ocean. Marine Biology Research 8:363372.

Silliman BR, Bertness M. 2002. A trophic cascade regulates salt marsh primary production. Proceedings of the National Academy of Science 99:10500-10505.

Stanhope H, Banta W, Temkin M. 1982. Size-specific emergence of the marsh snail, Littorina irrorata: effect of predation by blue crabs in a Virginia salt marsh. Gulf Research Reports 7:179-182.

Sueiro M, Bortolus A, Schwindt E. 2012. The rolde of the physical structure of Spartina densiflora Brong in structuring macroinvertebrate assemblages. Aquatic Ecology 46:2536.

Theil M, Gutow L. 2005. The ecology of rafting in the marine environment. I. The floating substrata. Oceanography and Marine Biology: An Annual Review 42:181-264

Theil M, Fraser C. 2016. The role of floating plants in dispersal of biota across habitats and ecosystems. In Olafsson E (ed) Marine Macrophytes as Foundation Species. CRC Press, Boca Raton, FL. Pp 76-94.

Trussell GC, Smith LD. 2000. Induced defenses in response to an invading crab predator: An explanation of historical and geographic phenotypic change. Proceedings of the National Academy of Science 97:2123-2127.

Trussell GC, Nicklin MO. 2002. Cue sensitivity, inducible defense, and trade-offs in a marine 
snail. Ecology 83:1635-1647.

526 Vaughn C, Fisher F. 1988. Vertical migration as a refuge from predation in intertidal marsh snail: a field test. Journal of Experimental Marine Biology and Ecology 123:163-176.

528 Vermeij G. 1982. Unsuccessful predation and evolution. The American Naturalist 120:701-720.

529 Vermeij G. 1983. Traces and trends of predation, with special reference to bivalved animals.

$530 \quad$ Palaeontology 26:455-465.

531 Vermeij G. 1987. Evolution and Escalation: an Ecological History of Life. Princeton University $532 \quad$ Press, Princeton, NJ.

533 Wang FC, Lu T, Sikora WB. 1993. Intertidal marsh suspended sediment transport processes, 534 Terrebonne Bay, Louisiana, USA. Journal of Coastal Research 9: 209-220

535 Warren J. 1985. Climbing as an avoidance behaviour in the salt marsh periwinkle, Littorina 536 irrorata (Say). Journal of Experimental Marine Biology and Ecology 89:11-28.

537 Wollerman L, Duva M, Ferrier MD. 2003. Responses of Littoraria irrorata Say (Mollusca: Gastropoda) to water-borne chemicals: A comparison of chemical sources and orientation mechanisms. Marine and Freshwater Behavior and Physiology 36:129-142.

540 Yoshida T, Jones LE, Ellner SP, Fussmann GF, Hairston, NG. 2003. Rapid evolution drives ecological dynamics in a predator-prey system. Nature 424:303-306.

542 Zacherl D, Gaines SD, Lonhart SI. 2005. The limits to biogeographical distributions: insights 543 from the northward range extension of the marine snail, Kelletia kelletii (Forbers, 1952). $544 \quad$ Journal of Biogeography 30:913-924 


\section{Figure 1}

Conceptual diagram and photograph of experimental box-within-a-box design

Conceptual diagram (A) of the box-within-a-box experimental design. Snails and Spartina mimics were places in the inner plastic box, and when a crab was present, it was placed in the outer box. Inner boxes were either perforated to allow water exchange (as shown in A) or kept solid to prevent water exchange. Photo (B) of the experimental set-up showing the mesh screen to prevent the crab from entering snail tubs and the PVC frames and black plastic curtains that surround each experimental unit to minimize mixing of cues. Symbols courtesy of the Integration and Application Network, University of Maryland Center for Environmental Science (ian.umces.edu/symbols/). Photo by CM Finelli.

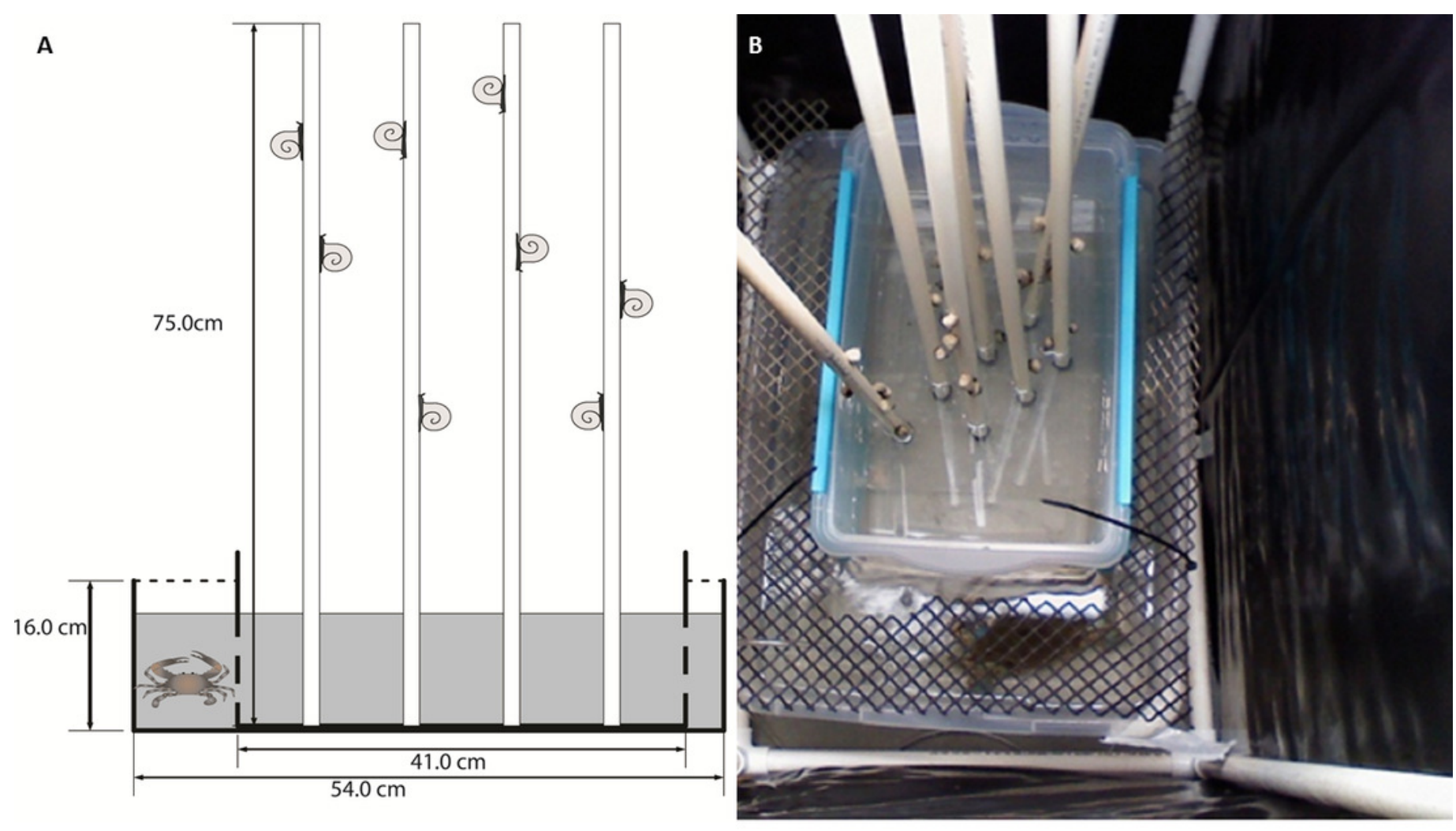


Figure 2

Climbing height of different snail populations across different cue treatments.

Climbing height in single population assemblages for Louisiana (light gray boxes) and North Carolina snails (dark gray boxes) in the presence of no cue, an airborne cue, and a waterborne cue. The boundaries of the box represent the $25^{\text {th }}$ and $75^{\text {th }}$ percentiles, the solid line represents the median, the whiskers are the $10^{\text {th }}$ and $90^{\text {th }}$ percentiles, and the dots represent outliers. Letters above the boxes indicate significant differences in post-hoc analysis.

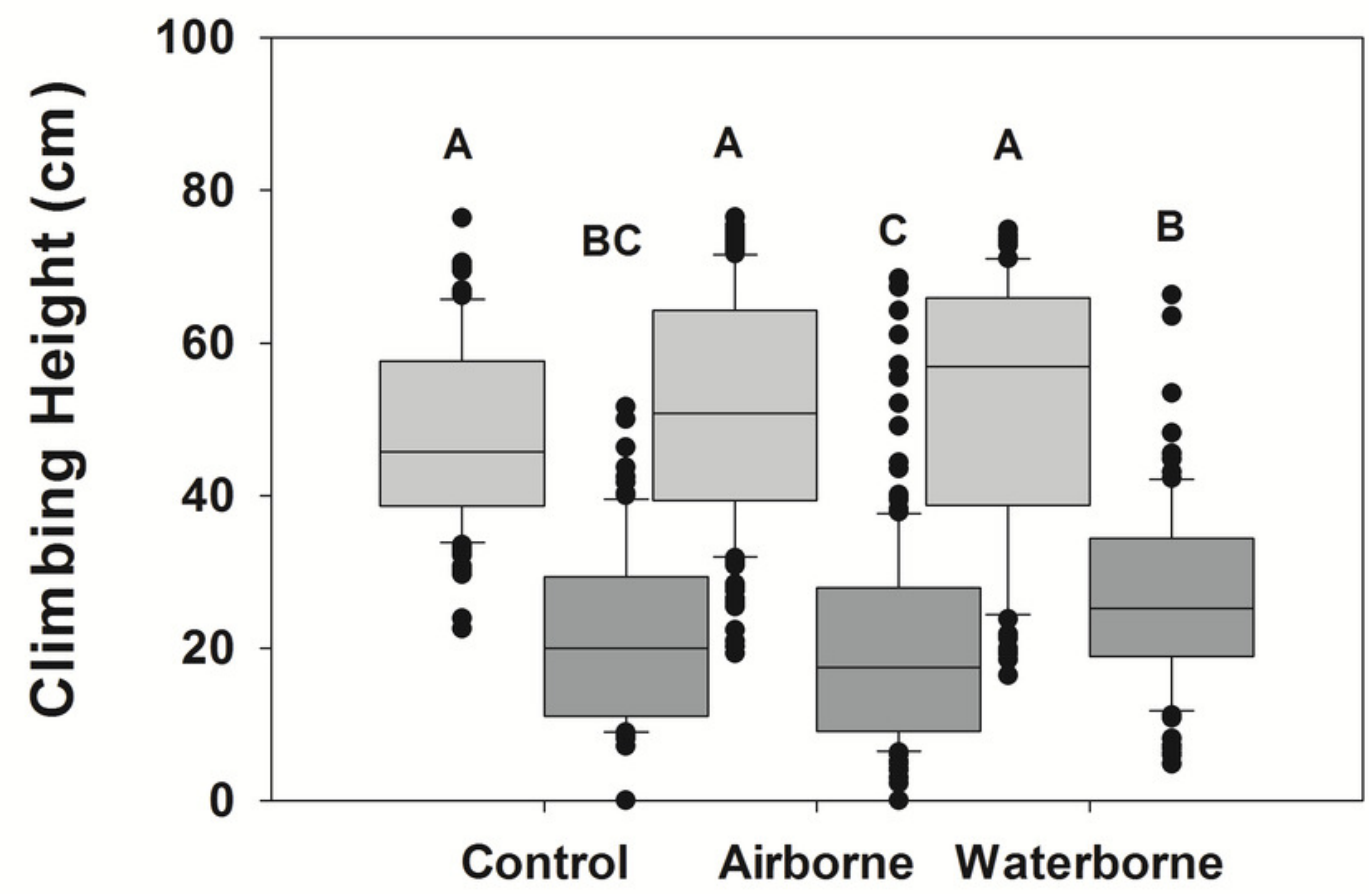




\section{Figure 3}

Climbing height for each population and cue treatment in the mixed-population assemblages

Differences in climbing height between the two populations (A) and across all three cue treatments (B) in the mixed-population assemblage experiment. The boundaries of the box represent the $25^{\text {th }}$ and $75^{\text {th }}$ percentiles, the solid line represents the median, the whiskers are the $10^{\text {th }}$ and $90^{\text {th }}$ percentiles, and the dots represent outliers. 


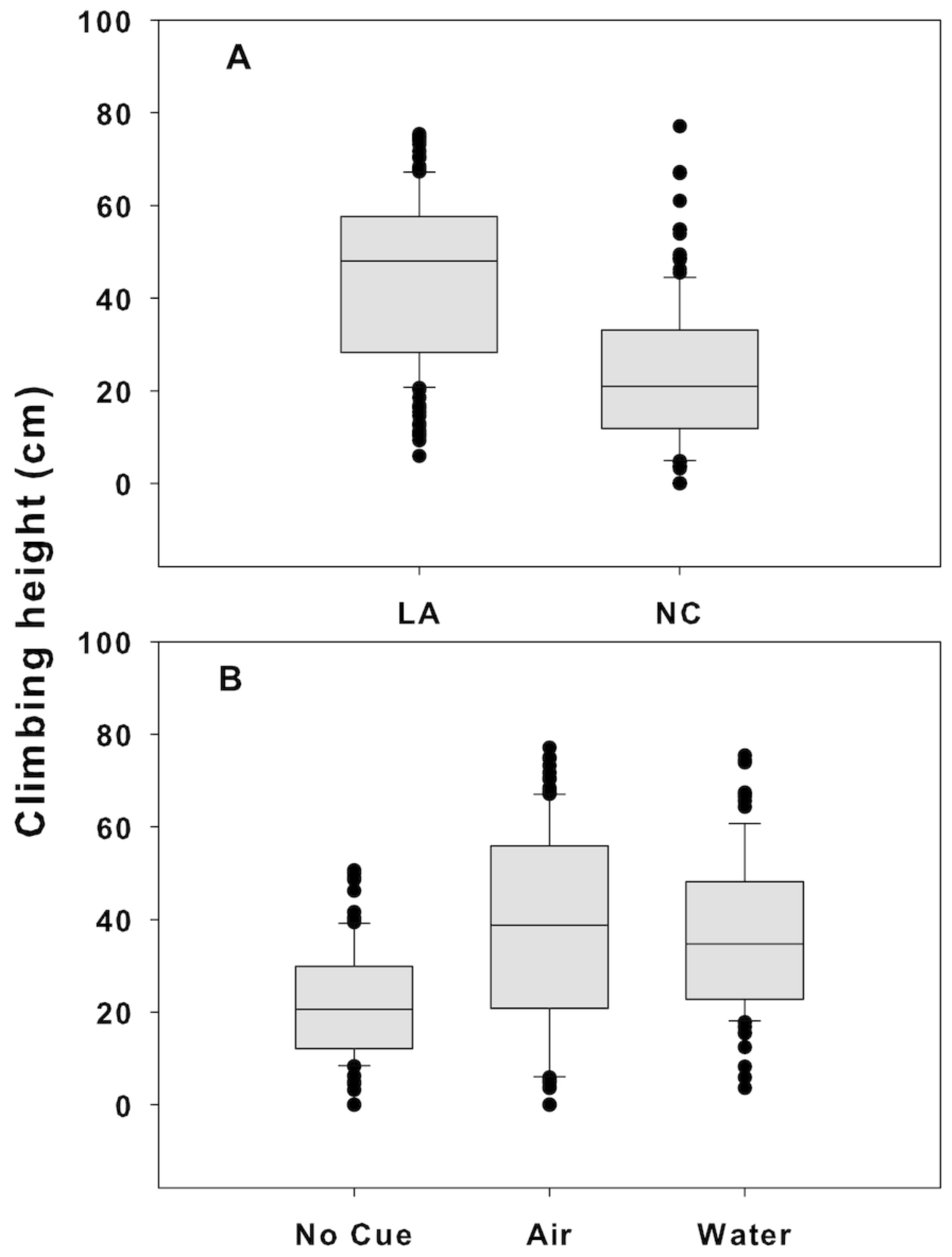


Figure 4

Landings of blue crabs in Louisiana and North Carolina

Blue crab landings from NOAA landings data for blue crabs in LA (solid line) and NC (dotted line) from 1950-2016.

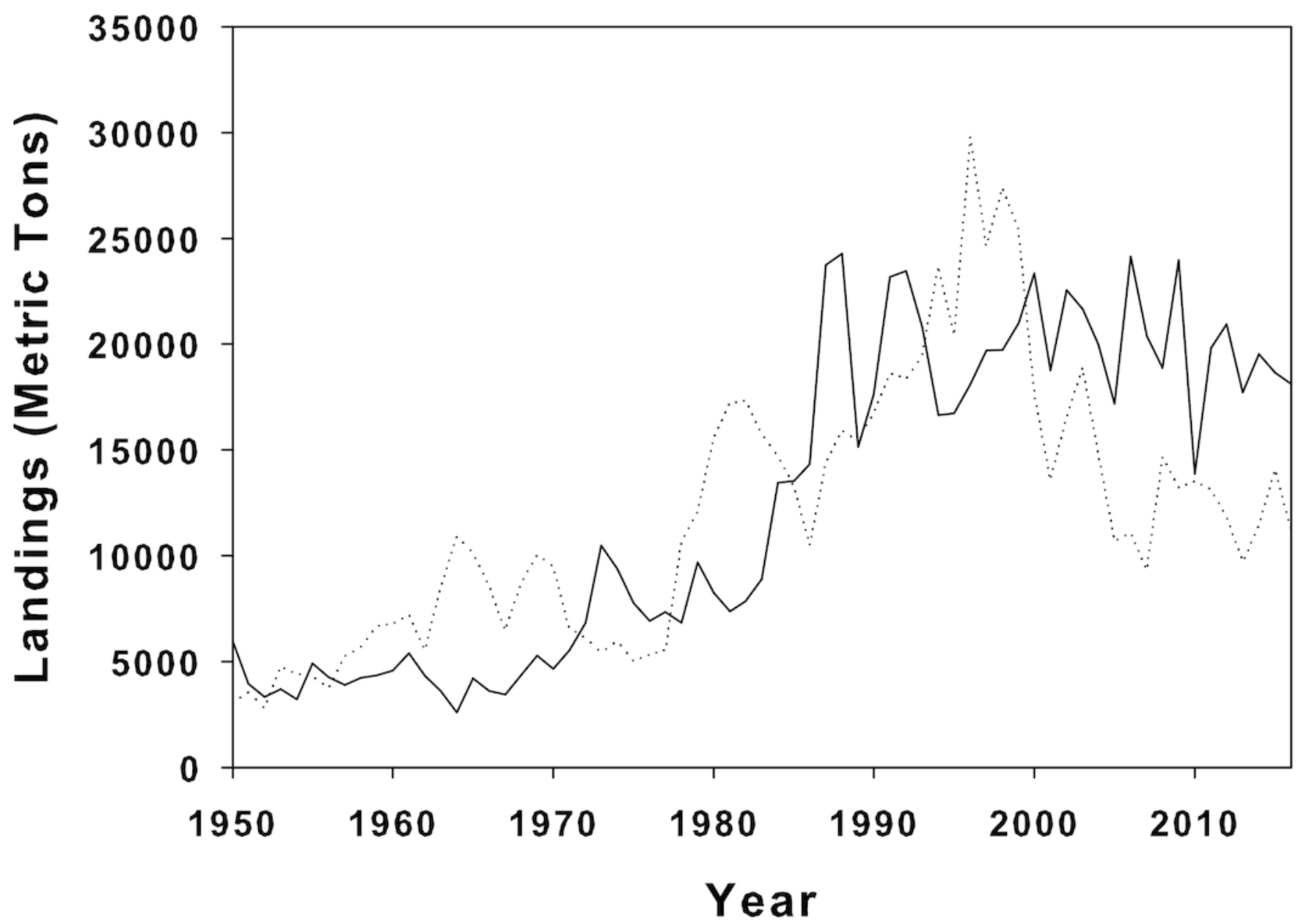




\section{Table $\mathbf{1}$ (on next page)}

Analysis of deviance table for mixed population experiments

Analysis of deviance table for differences in climbing height by site (LA and NC) and cue treatment (no cue, airborne cue, waterborne cue) in the mixed population assemblage using GLMM with site and cue treatment as the fixed factors and tub as the random effect. 
1 Response: Climbing Height

\begin{tabular}{|c|c|c|c|}
\hline & $\chi^{2}$ & Df & $\mathbf{p}$ \\
\hline \multirow{3}{*}{$\begin{array}{r}\text { Treatment } \\
\text { Site } \\
\text { Treatment } x \text { Site }\end{array}$} & 30.9221 & 2 & $1.929 \mathrm{e}-07 * * *$ \\
\hline & 63.6062 & 1 & $1.520 \mathrm{e}-15 * * *$ \\
\hline & 1.0741 & 2 & 0.5845 \\
\hline
\end{tabular}

2 